\title{
The Relative Importance of Intermediaries in eGovernment Adoption: A Study of Saudi Arabia
}

\author{
Faris Al-Sobhi, Vishanth Weerakkody, and Ramzi El-Haddadeh \\ Centre for Strategic Information Systems \\ Department of Information Systems \& Computing, Brunel University, Uxbridge, Middlesex \\ UB8 3PH \\ \{Faris.alsobhi, Vishanth.Weerakkody, \\ Ramzi.el-haddadeh\}@brunel.ac.uk
}

\begin{abstract}
Although Gulf countries have invested large sums of money in implementing e-government services, adoption rates have been low due to various social, political and demographic reasons. This study aims to provide a better understanding to citizens' adoption of e-government services through conceptualizing the role of intermediary organisations within e-government. In particular, this paper examines the importance of intermediaries in the adoption of e-government from a citizens' perspective and the potential influence they have on bridging digital divide in societies. Following previous studies on egovernment adoption, the study employs the unified theory of acceptance and use of technology (UTAUT) to examine the influence of intermediaries on citizens' adoption of e-government services in the context of Madinah city in Saudi Arabia. The results in this study indicates that the citizens' efforts towards using e-government services, their trust of the Internet and their trust of intermediary organisations contribute significantly towards their e-government adoption behaviour. Further, the facilitating conditions the intermediary organisations offer have a significant impact on the usage of e-government services.
\end{abstract}

Keywords: E-government, Intermediaries, Adoption, UTAUT.

\section{Introduction}

The adoption rate among citizens for e-government services determines its success or failure [16] [27][23]. Studies in this area has indicated that there are an increased emphasis on e-government adoption, exploring a number of significant factors affecting individual (citizens) adoption of e-government [9][2][10][5]. In particular interests have grown further in developing e-government systems and at the same time achieving its full potential. Governments worldwide have introduced various initiatives towards enhancing the effectiveness and efficiency of government services. Among these was the introduction of intermediary organizations under their e-government strategies [4][19]. Nevertheless, although concept of intermediary organizations adoption was introduced in other different contexts such as e-commerce, to date there has been little argument on the adoption of intermediary organization in the e-government realm 
[4][19]. While e-government services offered a number of benefits that fulfils its potential through engaging all relevant stakeholders, others who lack technology skills and have low level of education were often left out and have been excluded from these benefits. Consequently, this has created a significant gap and inequality in accessing egovernment services [20]. In this regard, many countries worldwide have established strategies to minimize digital divide and increase citizens' engagement new egovernment services that are implemented in their countries [5][8].

Over the last few years, in the developing world, Gulf countries in particular have invested large sums of money in e-government initiatives. Among these countries is Saudi Arabia. Saudi Arabia is a rich developing country in the Middle Eastern region that has started implementing national e-government projects since 1998 [24][1]. According to UN report, in the context of e-government readiness, Saudi Arabia significantly transformed its electronic service delivery from 2005 to 2008 [29] According to a recent report by Internet World Usage and Population Statistics, the total population in Saudi Arabia is around 28,146,657 and about $6,380,000$ Saudi citizens have Internet access. Despite a dramatic increase in the number of Internet users from about 200,000 in 2000 up to $6,380,000$ in recent years, a growth of about $3,090 \%$ (ibid), there are still delays in utilizing and adopting e-government services. In order to increase access to public services and effectively facilitate the usage of information technologies, Saudi Arabia's government attempted to deliver its public services through many channels. Among these channels are private-public-service offices (intermediaries). These offices are independent private organisations that offer a number of services to the public. They are used mainly to support access to public services and to collect required services fees from citizens. Although the use of intermediary organisations in the context of e-government diffusion is not entirely new, few studies have been conducted to examine their impact on e-government adoption. The rationale for undertaking this study is to further explore the impact of intermediary organizations in relation to improving the adoption of e-government services in Saudi Arabia. In order to realise this aim a research study is undertaken in Madinah city in Saudi Arabia. Madinah city launched its e-government services in 2003, and at present it is considered to be the second largest cultural city in Saudi Arabia. Madinah city is the only city that has implemented the e-government intermediary (referred to by Saudi's as e-office) concept under their local e-government initiatives. This research will examine the role of intermediaries in e-government adoption, using the case of the traffic department as an example of an e-government service in Saudi Arabia. Therefore, this study will be mainly focused on Saudi males as females are not allowed to drive in Saudi Arabia.

In order to achieve the above aim, section two begins by reviewing the theoretical background of intermediaries and factors influencing the adoption of e-government. This is followed by research methodology used for this study, offered in section three. Section four presents the research findings. Finally in section five, this paper will conclude by discussing the role of intermediaries in influencing the adoption of egovernment services in Saudi Arabia and outlining some recommendations for future research. 


\section{Theoretical Background}

As prior literature in the information systems (IS) and e-government realms show, few researchers have carried out studies that investigate the impact intermediaries on citizens' adoption and usage of e-government [4][19]. Most studies associated with egovernment adoption have been mainly focused on the individual level factors that impact citizens' attitudes toward e-government [9][5]. Further, studies have also highlighted the need to examine the adoption of e-services from the users' perspective, which are prompted by the roles of intermediaries [18][6]. However, studies that have focused on understanding citizens' behaviour when using intermediaries to access e-services have not utilized conceptual models to examine the influencing factors [4][19].

Since many researchers in the information systems field build their argument on a theoretical background [9][2][10][5], it is essential to present a theoretical model or framework that helps to understand the factors that affect the individual level (citizens) adoption of e-government services prompted by intermediaries. Users' acceptance and adoption of technologies is considered as a primary condition for a successful implementation of any IT project. This is due to the fact that users' attitudes to use and adopt new technologies plays an important role in the success or failure of these projects [23][27]. According to Venkatesh et al. [28 p. 446], users' acceptance of technology refers to the "initial decision made by the individual to interact with the technology". It has been found that numerous theories and models could be used to examine users' adoption of information technology (IT). For example, technology acceptance models (TAM), Theory of Reasoned Action (TRA), Theory of Planned Behaviour (TPB), the Motivational Model (MM) Diffusion of Innovation (DOI), the Model of PC Utilization (MPCU), Social Cognitive Theory (SCT), the model combined between TAM and TPB, and finally, the most recent model, the Unified Theory of acceptance and Use of Technology (UTAUT) could be used. The aim of the UTAUT model is to give a further complete explanation and prediction of users' behaviours that any older individual models could not have achieved alone. Each model mentioned above aimed to explain user behaviour and usage of new technology with a variety of independent variables; in fact, the UTAUT Model is proposed based on the similarities of these independent variables from each models cited above. According to the number of prior studies, the UTAUT model is the benchmark and most predictive model in the technology acceptance literature [2] [5]. The UTAUT model contains different factors that either directly affects usage behaviour as facilitating conditions or, affect behavioural intention by other determinant factors like performance expectancy, effort expectancy, and social influence. Also the UTAUT model considers moderator variables influencing the four direct determinant factors of behavioural intentions and usage behaviour such as gender, age, experience and voluntary use. This study adapts the UTAUT model. However, since this paper is a result of a preliminary study of the factors influencing e-government adoption in Saudi Arabia and the role that intermediaries play in the adoption process, the adapted UTAUT research model does not consider these moderators. 


\section{Conceptual Model and Research Hypothesis of E-Government Adoption in Saudi Arabia}

The literature review and theoretical background in section 2 has encouraged the authors of this paper to employee the UTAUT model as a framework to study the adoption of e-government in a Saudi context. While the research model used in this research was amended to suit the context of the study, the theoretical constructs included in the study are based on the literature reviewed above. A model depicting the impacts of e-government factors and intermediary roles in perceptions of enhancing intentions to e-government usage at the individual level (citizens) is presented in Figure 1. As such, the conceptual model proposed in this study uses the following factors from the UTAUT model.

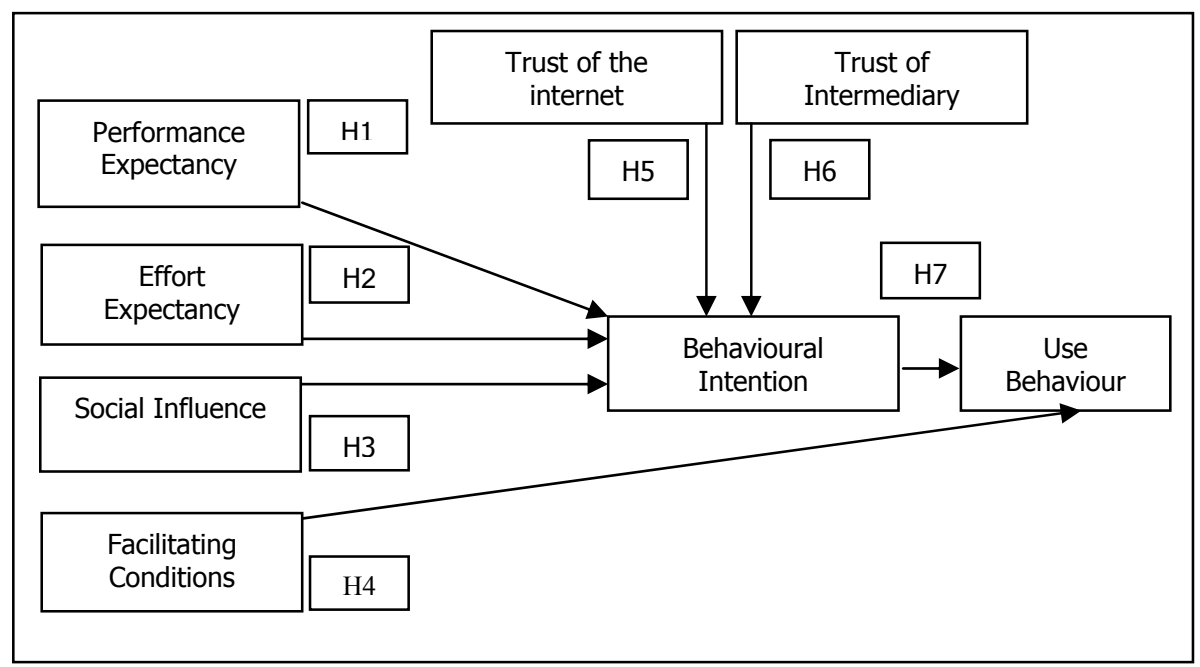

Fig. 1. Conceptual Model of Citizen Adoption of E-Government in Saudi Arabia

A number of studies have applied UTAUT to explore citizens' acceptance of egovernment in developed and developing countries, with many factors seen to be influential [9][2][10][5]. Therefore, it is very important to this study to consider these factors when investigating the role of intermediaries in relation to citizens' intention to use e-government services. In addition, it is necessary for this study to consider and incorporate additional factors into the UTAUT model that are specifically related to the Saudi Arabian context, for instance using intermediaries to facilitate e-government adoption. Table 1 presents a summary of constructs, definitions, and scales among the eight measures of e-government adoption used for this study. 
Table 1. Summary of Constructs, Definitions, and Scales of Intermediaries in E-government Model

\begin{tabular}{|c|c|c|c|}
\hline Constructs & Definition & $\begin{array}{l}\text { Item } \\
\text { Code }\end{array}$ & Items \\
\hline \multirow{7}{*}{$\begin{array}{c}\text { Performance } \\
\text { Expectancy } \\
\text { [28][13][14] } \\
{[21] .}\end{array}$} & \multirow{7}{*}{$\begin{array}{l}\text { In this } \\
\text { research, } \\
\text { performance } \\
\text { expectancy } \\
\text { refers to the } \\
\text { degree to } \\
\text { which an } \\
\text { individual } \\
\text { believes that } \\
\text { using the e- } \\
\text { government or } \\
\text { intermediary's } \\
\text { (e-office) } \\
\text { system will } \\
\text { help him or } \\
\text { her to attain } \\
\text { gains in } \\
\text { personal } \\
\text { performance }\end{array}$} & PE1 & $\begin{array}{l}\text { Using the Traffic department website will } \\
\text { enable me to renew my driving license more } \\
\text { quickly }\end{array}$ \\
\hline & & PE2 & $\begin{array}{l}\text { If I use the Traffic department website I will } \\
\text { enhance my social status }\end{array}$ \\
\hline & & PE3 & $\begin{array}{l}\text { Traffic department website would enable me } \\
\text { to access Traffic department information and } \\
\text { services when I need them - } 24 \text { hours/day, } 7 \\
\text { days/week }\end{array}$ \\
\hline & & PE4 & $\begin{array}{l}\text { If I use the Traffic department website I will } \\
\text { spend less time processing my driving license } \\
\text { renewal application }\end{array}$ \\
\hline & & PE5 & $\begin{array}{l}\text { I think interacting with the Traffic department } \\
\text { face to face would be preferable rather than } \\
\text { interacting online }\end{array}$ \\
\hline & & PE6 & $\begin{array}{l}\text { I think interacting with the Traffic department } \\
\text { through intermediaries (e-offices) would be } \\
\text { preferable to interacting face to face with traffic } \\
\text { department officials }\end{array}$ \\
\hline & & PE7 & $\begin{array}{l}\text { I think interacting with the Traffic department } \\
\text { through intermediaries (e-offices) would be } \\
\text { preferable to interacting directly with the traffic } \\
\text { department website }\end{array}$ \\
\hline \multirow{6}{*}{$\begin{array}{l}\text { Effort } \\
\text { Expectancy } \\
{[28][14]}\end{array}$} & \multirow{6}{*}{$\begin{array}{l}\text { In this } \\
\text { research, } \\
\text { effort } \\
\text { expectancy } \\
\text { refers to the } \\
\text { degree of } \\
\text { ease } \\
\text { associated } \\
\text { with use of e- } \\
\text { government } \\
\text { services }\end{array}$} & EE1 & $\begin{array}{l}\text { My interaction with the Traffic department } \\
\text { website would be clear and understandable }\end{array}$ \\
\hline & & EE2 & $\begin{array}{l}\text { It would be easy for me to become skilful at } \\
\text { using the Traffic department website }\end{array}$ \\
\hline & & EE3 & $\begin{array}{l}\text { Learning to interact with Traffic department } \\
\text { website would be easy for me }\end{array}$ \\
\hline & & EE4 & $\begin{array}{l}\text { I find it easy to get the Traffic department } \\
\text { website to do what I want it to do }\end{array}$ \\
\hline & & EE5 & $\begin{array}{l}\text { It would helpful to use intermediary (e-offices) } \\
\text { to interact with Traffic department online }\end{array}$ \\
\hline & & EE6 & $\begin{array}{l}\text { It would be helpful to interact online directly } \\
\text { with Traffic department }\end{array}$ \\
\hline \multirow{4}{*}{$\begin{array}{l}\text { Trust of } \\
\text { Intermediary }\end{array}$} & \multirow{4}{*}{$\begin{array}{l}\text { The degree } \\
\text { which } \\
\text { individual } \\
\text { (citizens) } \\
\text { believes that } \\
\text { intermediary is } \\
\text { a reliable tool } \\
\text { to be used to } \\
\text { obtain e- } \\
\text { government } \\
\text { services }\end{array}$} & TOl1 & I think I can trust intermediary organisations. \\
\hline & & TOI2 & $\begin{array}{l}\text { In my opinion, intermediary organisations are } \\
\text { trustworthy }\end{array}$ \\
\hline & & TOI3 & $\begin{array}{l}\text { The intermediaries (e-offices) have enough } \\
\text { safeguards (passwords, secure computers } \\
\text { etc.) to make me feel comfortable using it to } \\
\text { interact with the Traffic department online }\end{array}$ \\
\hline & & TOI4 & $\begin{array}{l}\text { I am not concerned that the information I } \\
\text { submit through the intermediaries (e-offices) } \\
\text { could be misused }\end{array}$ \\
\hline $\begin{array}{l}\text { Use Behaviour } \\
\qquad[28][14]\end{array}$ & $\begin{array}{l}\text { The actual use } \\
\text { and } \\
\text { associated } \\
\text { behaviour of } \\
\text { the e- } \\
\text { government } \\
\text { services. }\end{array}$ & UB & $\begin{array}{l}\text { Have you ever completed a transaction with } \\
\text { the Traffic department online? }\end{array}$ \\
\hline $\begin{array}{c}\text { Social } \\
\text { Influence }\end{array}$ & $\begin{array}{l}\text { In the current } \\
\text { study, social }\end{array}$ & SI1 & $\begin{array}{l}\text { People who influence my behaviour think I } \\
\text { should use the online Traffic department }\end{array}$ \\
\hline
\end{tabular}


Table.1 (Continued)

\begin{tabular}{|c|c|c|c|}
\hline \multirow{5}{*}{$\begin{array}{l}{[28][15]} \\
{[14][2]}\end{array}$} & \multirow{5}{*}{$\begin{array}{l}\text { influence is } \\
\text { defined as the } \\
\text { important } \\
\text { people } \\
\text { pressure } \\
\text { (family or } \\
\text { friends) that } \\
\text { influences the } \\
\text { intentions to } \\
\text { use e- } \\
\text { government, } \\
\text { and the } \\
\text { influence of an } \\
\text { intermediary in } \\
\text { increasing the } \\
\text { awareness } \\
\text { and the social } \\
\text { marketing to } \\
\text { adopt e- } \\
\text { government } \\
\text { services }\end{array}$} & & services \\
\hline & & SI2 & $\begin{array}{l}\text { I would use the e-government services if my } \\
\text { friends use them }\end{array}$ \\
\hline & & SI3 & $\begin{array}{l}\text { My Friends think intermediaries (e-offices) are } \\
\text { helpful for using the Traffic department online } \\
\text { service }\end{array}$ \\
\hline & & SI4 & $\begin{array}{l}\text { The intermediaries (e-offices) encourage the } \\
\text { use of online Traffic department services }\end{array}$ \\
\hline & & SI5 & $\begin{array}{l}\text { People who are important to me think that I } \\
\text { should use the Traffic department website } \\
\text { facilities }\end{array}$ \\
\hline \multirow{6}{*}{$\begin{array}{c}\text { Facilitating } \\
\text { Conditions } \\
\text { [28] [2] }\end{array}$} & \multirow{6}{*}{$\begin{array}{l}\text { The degree } \\
\text { which citizens } \\
\text { believe that } \\
\text { organisational } \\
\text { (intermediary) } \\
\text { and technical } \\
\text { infrastructure } \\
\text { support in } \\
\text { using e- } \\
\text { government } \\
\text { services and } \\
\text { remove } \\
\text { barriers in } \\
\text { such } \\
\text { relationships }\end{array}$} & FC1 & $\begin{array}{l}\text { I have the computer devise necessary to use } \\
\text { the Traffic department website }\end{array}$ \\
\hline & & $\mathrm{FC} 2$ & $\begin{array}{l}\text { I have access to the internet to use the Traffic } \\
\text { department website }\end{array}$ \\
\hline & & FC3 & $\begin{array}{c}\text { I have the internet experience necessary to } \\
\text { use the Traffic department website }\end{array}$ \\
\hline & & FC4 & $\begin{array}{c}\text { Given the resources, opportunities and } \\
\text { knowledge it takes to use the Traffic } \\
\text { department website, it would be easy for me to } \\
\text { use the Traffic department website }\end{array}$ \\
\hline & & FC5 & $\begin{array}{c}\begin{array}{c}\text { Guidance was available to me in the selection } \\
\text { of the system }\end{array} \\
\end{array}$ \\
\hline & & FC6 & $\begin{array}{l}\text { A specific person (or group) is available for me } \\
\text { in the intermediaries (e-offices) to provide } \\
\text { assistance with Traffic department website } \\
\text { difficulties }\end{array}$ \\
\hline \multirow{4}{*}{$\begin{array}{l}\text { Trust In } \\
\text { Internet } \\
{[9]}\end{array}$} & \multirow{4}{*}{$\begin{array}{l}\text { The degree } \\
\text { which citizens } \\
\text { believe that } \\
\text { internet is } \\
\text { reliable to be } \\
\text { used in } \\
\text { communicatin } \\
\text { g with } \\
\text { government } \\
\text { online. }\end{array}$} & TI1 & $\begin{array}{l}\text { The internet has enough safeguards to make } \\
\text { me feel comfortable interacting with the Traffic } \\
\text { department website }\end{array}$ \\
\hline & & $\mathrm{TI} 2$ & $\begin{array}{l}\text { I feel assured that legal and technological } \\
\text { structures adequately protect me from } \\
\text { problems on the internet }\end{array}$ \\
\hline & & $\mathrm{TI} 3$ & $\begin{array}{l}\text { I feel secure sending sensitive information } \\
\text { across the internet }\end{array}$ \\
\hline & & $\mathrm{TI} 4$ & $\begin{array}{l}\text { In general, the internet is now a robust and } \\
\text { safe environment in which to transact with the } \\
\text { Traffic department }\end{array}$ \\
\hline \multirow{4}{*}{$\begin{array}{l}\text { Behavioural } \\
\text { Intention } \\
\text { [28] [2][13] }\end{array}$} & \multirow{3}{*}{$\begin{array}{l}\text { In this study } \\
\text { the } \\
\text { behavioural } \\
\text { intention is } \\
\text { defined as the } \\
\text { degree to } \\
\text { which citizens } \\
\text { intend to use } \\
\text { the Internet or } \\
\text { an }\end{array}$} & $\mathrm{BI} 1$ & I intend to use the Traffic website in future \\
\hline & & $\mathrm{BI} 2$ & $\begin{array}{l}\text { I intend to use the Traffic department website } \\
\text { directly }\end{array}$ \\
\hline & & $\mathrm{BI} 3$ & $\begin{array}{l}\text { I intend to use the Traffic department website } \\
\text { through intermediaries (e-offices) in the future }\end{array}$ \\
\hline & $\begin{array}{l}\text { intermediary } \\
\text { for e- } \\
\text { government } \\
\text { services in the } \\
\text { future. }\end{array}$ & & \\
\hline
\end{tabular}


According to the above discussion and UTAUT literatures [28] the authors have formulate the following hypotheses:

H1: Performance expectancy will have a positive influence on behaviour intention to use e-government services.

H2: Effort expectancy will have a positive influence on behaviour intention to use e-government services.

H3: Social influence will have a positive influence on behaviour intention to use egovernment.

H4: Facilitating conditions will have a positive influence on e-government usage behaviour.

H5: Behavioural intentions to use e-government services will have a positive influence on e- government usage behaviour.

H6: Trust on in the Internet will have a positive influence on behavioural intentions to use e-government services.

H7: Trust in the Intermediaries (e-offices) will have a positive influence on behavioural intentions to use e-government services.

\section{Research Approach}

A quantitative approach is the primary method that was used to collect the data for this research. To assess the research model proposed in the study, a questionnaire survey was used. The advantages of using the questionnaire are that it is easy to distribute in different locations at the same time and costs less [7]. The questionnaire used for this study consisted of 43 questions and included single answer, multiple choice, closed-ended, and 5-point Likert scale questions, which ranged from strongly disagree to strongly agree. After the questionnaire was built, a pre-test was done using six researchers and three practitioners in order to improve the questions and enhance the comprehension of respondents before final distribution [25]. As the questionnaire was designed in English and the targeted research context is an Arabic country (Saudi Arabia), the authors converted the questionnaire into Arabic and validated the translation by sending the questionnaire to four academic staff from a Saudi university. In the questionnaire, a brief explanation about e-government and purpose of the study was provided for the benefit of the participants. The main aim of this study was to explore the roles of intermediaries in the adoption of e-government; therefore, the sample selected was influenced by the objectives of this study to examine the impact that intermediaries may have on digital divide factors that affect individuals' (citizens) adoption of e-government. Thus, the sample of this research was aimed at all citizens in Madinah. The survey questionnaires were then distributed randomly to 750 citizens in Madinah, from September to December 2010 of which 626 respondents were found to be useful (83.4\% of total survey), and 124 were discarded because of incomplete answers (90), or because they were completed by females (34). All of the participants were males; this is because this research looked at the Saudi traffic department as the example of e-government services in Madinah city, and females were eliminated from the questionnaire survey since they do not have the 
right to drive in Saudi Arabia. The items of this survey were adopted from Venkatesh et al. [28] and modified to meet the research objectives. In addition, some items were built based on intermediaries' literature in order to understand the roles of intermediaries in facilitating e-government adoption.

\section{Data Analysis}

The proposed research model consisted of six independent variables: performance expectancy, effort expectance, social influence, facilitating conditions, trust of Internet, trust of intermediaries, and two dependent variables: intention behaviour and use behaviour. To check the responses of these questions, the first stage consisted of checking the responses and tagging them with a unique number. The author generated the descriptive statistics (percentages and tables) and used Linear Regression analysis by utilising SPSS (Version 18.0). Descriptive data analysis provides the reader with an appreciation of the actual numbers and values, and hence, the scale that researchers are dealing with [12].

\subsection{Descriptive Statistics}

Out of the verified respondents, the descriptive statistics are as follows. In terms of age, $50.8 \%$ of the respondents were between the ages of 18 and 30, 40.4\% were between 31 and 45, and 6.95\% were between 45 and 54. Additionally, $1.9 \%$ of respondents were younger than 18 or older than 54 years old. As summarised in table 2 , the average scores for respondents of performance expectance ranged from 3.88 to 3.01 (where $1=$ minimum and $5=$ maximum). Descriptive statistics show that these scores are high. For effort expectance, the score ranged from 3.42 and 3.82, which is also high. Concerning social influence, the result shows that the mean ranges from 3.42 to 3.66. According to the facilitating conditions construct the score ranges between 3.38 and 3.89. The score for behaviour intention construct ranges between 3.34 and 3.80. For trust of internet construct the mean score ranged between 3.32 and 3.55. Finally the trusts of intermediary construct score range between 3.26 and 3.38 .

As presented above in table 2, most of the respondents scored to be neutral, this is due to the fact that the concept of e-government services in Saudi Arabia is relatively new. According to the statistical results of the questionnaire, the 30-44 age group has the most usage of Internet applications (37.6\%). This is followed by the 25-29 age group $(27.7 \%)$ and the $18-24$ age group at approximately $21.4 \%$. The age group between 45 and 54 years old has around $5.5 \%$ who are Internet users in Saudi Arabia. The under 18 age group and older than 54 age group are combined to be $1.26 \%$ of Internet users. As for adopting e-government services among citizens in Madinah, it has been found that the age group between 30 and 44 years $(26.6 \%)$ were the highest adopters. This is followed by the 25-29 age group (18.05\%) and the 18-24 age group at around 13.4\%. Those younger than 18 and older than 54 age groups are collectively represented by $1.1 \%$. These statistical result shows that the Internet and egovernment is distributed between 18 and 44 years. 
Table2. Descriptive Statistics

\begin{tabular}{|c|c|c|c|c|c|}
\hline Factors & Mean & Std. Dev. & Factors & Mean & Std. Dev. \\
\hline $\begin{array}{l}\text { 1- Performance } \\
\text { Expectancy }\end{array}$ & & & $\begin{array}{l}\text { 5- Behavioural } \\
\text { Intention }\end{array}$ & & \\
\hline PE1 & 3.86 & 1.210 & BI1 & 3.73 & 1.213 \\
\hline PE2 & 3.37 & 1.229 & BI2 & 3.80 & 1.160 \\
\hline PE3 & 3.88 & 1.138 & $\mathrm{BI} 3$ & 3.34 & 1.278 \\
\hline PE4 & 3.87 & 1.172 & & & \\
\hline PE5 & 3.01 & 1.391 & & & \\
\hline PE6 & 3.30 & 1.357 & & & \\
\hline PE7 & 3.09 & 1.330 & & & \\
\hline $\begin{array}{l}\text { 2- Effort } \\
\text { Expectancy }\end{array}$ & & & $\begin{array}{l}\text { 6-Trust Of } \\
\text { Internet }\end{array}$ & & \\
\hline EE1 & 3.68 & 1.063 & TI1 & 3.55 & 1.161 \\
\hline EE2 & 3.81 & 1.069 & TI2 & 3.50 & 1.164 \\
\hline EE3 & 3.79 & 1.096 & TI3 & 3.32 & 1.181 \\
\hline EE4 & 3.67 & 1.162 & TI4 & 3.54 & 1.162 \\
\hline EE5 & 3.42 & 1.277 & & & \\
\hline EE6 & 3.81 & 1.131 & & & \\
\hline $\begin{array}{l}\text { 3- Social } \\
\text { influence }\end{array}$ & & & $\begin{array}{l}\text { 7-Trust Of } \\
\text { Intermediary }\end{array}$ & & \\
\hline SI1 & 3.66 & 1.054 & TOI1 & 3.38 & 1.196 \\
\hline SI2 & 3.63 & 1.093 & TOI2 & 3.38 & 1.184 \\
\hline SI3 & 3.46 & 1.169 & TOI3 & 3.38 & 1.225 \\
\hline SI4 & 3.55 & 1.190 & TOI4 & 3.29 & 1.275 \\
\hline SI5 & 3.42 & 1.212 & & & \\
\hline \multicolumn{6}{|l|}{$\begin{array}{l}\text { 4- Facilitating } \\
\text { Condition }\end{array}$} \\
\hline $\mathrm{FC} 1$ & 3.57 & 1.247 & & & \\
\hline FC2 & 3.56 & 1.217 & & & \\
\hline FC3 & 3.78 & 1.152 & & & \\
\hline FC4 & 3.89 & 1.102 & & & \\
\hline FC5 & 3.54 & 1.138 & & & \\
\hline FC6 & 3.38 & 1.219 & & & \\
\hline
\end{tabular}

\subsection{Reliability Analysis}

Cronbach's coefficient alpha values were chosen to examine the internal consistency of the measure [17]. Hinton et al. [17] have suggested four different points of reliability: excellent $(0.90$ and above), high $(0.70-0.90)$, high moderate $(0.50-0.70)$ and low ( 0.50 and below). The reliability for each construct is illustrated in Table 3 .

The high Cronbach's Alpha value indicates that the constructs were internally consistent and the reliability is measured from the same construct. The Cronbach's results varied between 0.785 for the performance expectancy and 0.897 for the trust of intermediary constructs. According to the above results (table 3), all five constructs present high reliability in predicting intention behaviour toward e-government services. The Cronbach's value showed that the appropriate level of internal consistency of the model construct is satisfied. A regression analysis was used to measure the influence of independent variables on the behavioural intention to adopt e-government services promoted by the roles of intermediaries in a Saudi Arabian context. Five factors were proposed to predict behavioural intention: performance 
Table 3. Reliability Test of the model

\begin{tabular}{|l|l|l|l|l|}
\hline \multicolumn{1}{|c|}{$\begin{array}{c}\text { Model } \\
\text { Constructs }\end{array}$} & $\begin{array}{c}\text { Cronbach } \\
\text { s Alpha }\end{array}$ & $\begin{array}{l}\text { Number } \\
\text { Of Items }\end{array}$ & \multicolumn{1}{c|}{ Result } & \multicolumn{1}{c|}{$\begin{array}{c}\text { Oo Of } \\
\text { Participants }\end{array}$} \\
\hline Performance Expectancy (PE) & .758 & 7 & High Reliability & 624 \\
\hline Effort Expectancy (EE) & .801 & 6 & High Reliability & 611 \\
\hline Social Influence (SI) & .763 & 5 & High Reliability & 621 \\
\hline Facilitating Conditions (FC) & .797 & 6 & High Reliability & 601 \\
\hline Behavioural Intention to Use(BI) & .677 & 3 & High Moderate & 598 \\
\hline Trust of Internet (TI) & .863 & 4 & High Reliability & 621 \\
\hline Trust of intermediary (TIO) & .897 & 4 & High Reliability & 615 \\
\hline
\end{tabular}

expectancy, effort expectancy, social influence, trust of technology (Internet) and trust of intermediary. The $\mathrm{R}$ square accounted for 0.454 (table 4), which means that independent variables of Performance Expectancy (PE), Effort Expectancy (EE), Social Influence (SI), Trust of Internet (TI) and trust of intermediary (TOI) explain an additional $45 \%(0.454 \times 100)$ of the variance in behavioural intention to use egovernment services; and this is a statistically significant contribution $(\mathrm{Sig} .=.000)$. Further, the result showed that the model is statistically significant $(\mathrm{F}(51.096)=$ 102.989, $\mathrm{P}<0.001)$.

Table 4. Regression analysis coefficients (dependent variable)

(a) Predictors - ANOVA (b) - Coefficients (c)

\begin{tabular}{|c|c|c|c|c|c|c|}
\hline Model & $\mathrm{R}$ & R Square & $\begin{array}{l}\text { Adjusted R } \\
\text { Square } \\
\end{array}$ & $\begin{array}{l}\text { Std. Error } \\
\text { of the } \\
\text { Estimate }\end{array}$ & & \\
\hline 1 & $.674(a)$ & .454 & .449 & .704 & & \\
\hline \multicolumn{2}{|l|}{ Model } & $\begin{array}{l}\text { Sum of } \\
\text { Squares }\end{array}$ & df & $\begin{array}{l}\text { Mean } \\
\text { Square }\end{array}$ & F & Sig. \\
\hline \multirow[t]{2}{*}{1} & $\begin{array}{l}\text { Regression } \\
\text { Residual }\end{array}$ & $\begin{array}{l}255.482 \\
307.604\end{array}$ & $\begin{array}{l}5 \\
620\end{array}$ & $\begin{array}{l}51.096 \\
.496\end{array}$ & 102.989 & $.000(a)$ \\
\hline & Total & 563.086 & 625 & & & \\
\hline \multicolumn{2}{|l|}{ Model } & \multicolumn{2}{|c|}{ Unstandardized Coefficients } & $\begin{array}{l}\text { Standardize } \\
\text { d } \\
\text { Coefficient } \\
\mathrm{S}\end{array}$ & \multirow{2}{*}{$\mathrm{T}$} & \multirow{2}{*}{ Sig. } \\
\hline & & B & Std. Error & Beta $(\beta)$ & & \\
\hline \multirow[t]{6}{*}{1} & (Constant) & .397 & .150 & & 2.656 & .008 \\
\hline & PE & .087 & .048 & .074 & 1.794 & .073 \\
\hline & $\mathrm{EE}$ & .379 & .052 & .321 & 7.319 & .000 \\
\hline & SI & .088 & .048 & .076 & 1.820 & .069 \\
\hline & TI & .213 & .036 & .221 & 5.952 & .000 \\
\hline & TOI & .140 & .032 & .157 & 4.320 & .000 \\
\hline $\begin{array}{l}\text { (A) } \\
\text { (B) } \\
\text { (C) }\end{array}$ & $\begin{array}{l}\text { lictors: (Const } \\
\text { endent Variab } \\
\text { ficients }\end{array}$ & $\begin{array}{l}\text { t), PE, EE, SI, } \\
\text { BI }\end{array}$ & & & & \\
\hline
\end{tabular}


Table 5. Logistic Regression of Saudi e-government Model

\begin{tabular}{|c|c|c|c|c|c|c|c|}
\hline \multicolumn{8}{|c|}{ Variables in the Equation } \\
\hline & & $\mathrm{B}$ & S.E. & Wald & $\mathrm{df}$ & Sig. & $\operatorname{Exp}(B)$ \\
\hline \multirow[t]{3}{*}{ Step 1a } & \multirow{3}{*}{$\begin{array}{l}\mathrm{FC} \\
\mathrm{BI} \\
\text { Constant }\end{array}$} & .339 & .124 & 7.497 & 1 & .006 & 1.404 \\
\hline & & .099 & .107 & .854 & 1 & .355 & 1.104 \\
\hline & & $-1.895-$ & .415 & 20.884 & 1 & .000 & .150 \\
\hline
\end{tabular}

Three predictors of the current model were found to be significant. According to the above results (table 4 ), the significant variables are as follows: effort expectancy $(\beta=.321, p=.000)$, trust of Internet $(\beta=.221, p=.000)$, and trust of intermediary $(\beta=.157$, $\mathrm{p}=.000)$. Further, in this study, the beta $(\beta)$ size showed that the most important factor influencing the behaviour intention to adopt e-government services is effort expectancy. The second influential factor that impacts the explanation of the behaviour intention is trust in Internet construct, followed by trust of intermediary construct. Further, performance expectancy and social influence construct are not making any unique significant contributions to the prediction of behaviour intention in the Saudi Arabia egovernment context. Nonetheless, when dependent variables of the study are categorical (e.g. usage behaviour construct in this study represented by Yes/No) logistic regression was found to be suitable [22]. In this research the dependent variable (usage behaviour) was coded as $1=$ Yes and $0=$ No. As shown in table 5 facilitating conditions contribute significantly to the usage behaviour of e-government services $(\mathrm{p}=.006<.05)$. However, behaviour intention showed to have no unique contribution in usage behaviour of egovernment $(\mathrm{p}=.355>.05)$.

\section{Discussions and Conclusions}

While a strong relationship between age differences and e-government adoption has been reported in the literature, the statistical analysis of this study shows that the people most adopting e-government in Saudi Arabia is between 18 and 44 years. This shows that the older people can be categorised as non-adopter of e-government, and may therefore need further help and support towards e-government adoption. Furthermore, in reviewing the prior studies, no statistical data was found on the association between intermediary and e-government adoption. This study found that there is a significant relationship between three constructs (effort expectance, trust of internet and trust of intermediary) and e-government adoption behaviour, showing that there is strong support for the hypotheses proposed in this study $(\beta=.321$, $\mathrm{p}<.01)$, trust of Internet $(\beta=.221, \mathrm{p}<.01)$, and trust of intermediary $(\beta=.157, \mathrm{p}<.01)$. The resulting implication is that, having these three constructs plays a strong role in determining e-government adoption. Further, this study found that there is a significant relationship between the facilitating conditions construct and usage of egovernment services, which clearly indicates that the more facilitating conditions (intermediaries) Saudi e-government have the more barriers that will be removed, furthering the citizens engagement with e-government. 
Cronbach's Alpha was found an appropriate tool to measure the reliability of independent variables in accordance with behavioural intention to adopt egovernment services. Literature indicated that reliability in an exploratory study should be equal to or higher than 0.60 (Dwivedi et al., 2007; Straub et al., 2004). The current study showed that (see table 3 ) all constructs were found to be above 0.60 which means all of them obtained the level of internal consistency of measurement. Further, the present study adds to our understanding of the role of intermediaries in working in parallel with different constructs in explaining behavioural intentions with regard to the adoption of e-government and confirms previous findings (Chatterjee, 2008). Intermediary theory suggests that the most important roles of intermediaries are to enhance trust between two parties (Bailey \& Bakos, 1997). This is confirmed by the empirical findings in this study. Furthermore, Carter and Belanger (2005) stated that trust is an important factor that affects citizens' adoption of e-government services. Also, this study suggests that intermediaries are essential, particularly for developing countries as they develop their infrastructure to bridge technical gaps and digital divide. The major theoretical implications of these research findings are that citizens' adoption and usage of e-government can be explained by trust of intermediaries; the intermediary organisations can enhance trust between government and citizens increasing adoption. A second implication for e-government theory is that, using intermediaries in e-government can facilitating e-government usage, and be able to predict usage behaviour. Since this paper is a result of a preliminary study, several limitations need to be considered. In particular, this study does not measure the moderator variables in UTAUT. Therefore, considering the moderator variables could further explains the main constructs that determine behavioural intention to use e-government services and usage behaviour. Furthermore, the empirical work can be further extended to cover other e-government services beyond the traffic department example used in this study which only considered males.

\section{References}

1. Abanumy, A., Al-Badi, A., Mayhew, P.: E-government Website accessibility: in-depth evaluation of Saudi Arabia and Oman. Electronic Journal of e-Government 3(3), 99-106 (2005)

2. Ajzen, I.: The Theory of Planned Behaviour. Organizational Behavior and Human Decision Processes 50(2), 179-211 (1991)

3. Alawadhi, S., Morris, A.: The Use of the UTAUT Model in the Adoption of E government Services in Kuwait. In: Proceedings of the 41st Hawaii International Conference on System Sciences, pp. 1-11 (2008)

4. Al-Sobhi, F., Weerakkody, V., Kamal, M.M.: An exploratory study on the role of intermediaries in delivering public services in Madinah City: Case of Saudi Arabia. Transforming Government: People, Process and Policy 4(1), 14-36 (2010)

5. Al-Shafi, S., Weerakkody, V.: Factors affecting e-government adoption in the state of Qatar. In: European and Mediterranean Conference on Information Systems (Emcis), Abu Dhabi, UAE, April 12-13 (2010)

6. Bailey, J., Bakos, Y.: An exploratory study of the emerging role of electronic Intermediaries'. International Journal of Electronic Commerce 1(3), 7-20 (1997)

7. Bryman, A., Bell, E.: Business research methods, 2nd edn. Oxford University Press, Oxford (2007) 
8. Cabinet Office.: Transformational Government - Enabled by Technology. Strategy Document. London, UK (2005)

9. Carter, L., Belanger, F.: The utilization of e-government services: citizen trust, innovation and acceptance factors. Information Systems Journal 15(1), 5-25 (2005)

10. Carter, L., Weerakkody, V.: E-Government Adoption: A Cultural Comparison, Information Systems Frontiers, vol. 10(4), pp. 473-482. Springer, Heidelberg (2008)

11. Dwivedi, Y.K., Khoumbati, K., Williams, M.D., Lal, B.: Factors affecting consumers' behavioural intention to adopt broadband in Pakistan'. Transforming Government People, Process and Policy 1(3), 285-297 (2007)

12. Dwivedi, Y., Weerakkody, V.: Examining the factors affecting the adoption of broadband in the Kingdom of Saudi Arabia. Electronic Government, An International Journal 4(1), 43-58 (2007)

13. Davis, F.D.: Perceived Usefulness, Perceived Ease of Use, and User Acceptance of Information Technology. MIS Quarterly 13(3), 319-339 (1989)

14. Davis, F.D., Bagozzi, R.P., Warshaw, P.R.: User Acceptance of Computer Technology: A Comparison of Two Theoretical Models. Management Science 35(8), 982-1003 (1989)

15. Fishbein, M., Ajzen, I.: Belief, attitude, intention and behavior: An introduction to theory and research (1975)

16. Heeks, R.: e-government as a Carrier of Context. Journal of Public Policy 25(1), 51-74 (2005)

17. Hinton, P.R., Brownlow, C., McMurvay, I., Cozens, B.: SPSS explained. Routledge Inc., East Sussex (2004)

18. Howells, J.: Intermediation and the role of intermediaries in innovation'. Research Policy 35, 715-728 (2008)

19. Janssen, M., Klievink, B.: The Role Of Intermediaries In The Multi-Channel Services Delivery Strategies'. International Journal Of Electronic Government Research 5(3), 36-46 (2009)

20. Margetts, H., Dunleavy, P.: Cultural barriers to e-government. Academic article in support of better public services through e-government. National Audit Office, Ordered by the House of Commons, London (2002)

21. Moore, G.C., Benbasat, I.: Development of an instrument to measure the perceptions of adopting an information technology innovation. Information systems research 2, 192 (1991)

22. Pallant, J.: SPSS Survival Manual: A step by step guide to data analysis using SPSS for Windows (Version 15), 3rd edn. Allen and Unwin, Crows Nest (2007)

23. Pinto, J., Mantel, S.: The causes of project failure. IEEE Transactions on Engineering Management 37(4), 267-269 (1990)

24. Sahraoui, S., Gharaibeh, G., Al-Jboori, A.: Government in Saudi Arabia can it overcome its challenges?'. In: EGOV 2006. Brunel University (2006)

25. Saunders, M., Lewis, P., Thornhill, A.: Research methods for business students, 3rd edn. Prentice Hall, Harlow (2002)

26. Straub, D., Boudreau, M.-C., Gefen, D.: Validation Guidelines for IS Positivist Research Communications of the AIS. 13(24), 380-427 (2004)

27. Succi, M.J., Walter, Z.D.: Theory of user acceptance of information technologies: an examination of health care professionals'. In: System Sciences Proceedings of the 32nd Hawaii International Conference on System Sciences (HICSS), Track4, p. 7 (1999)

28. Venkatesh, V., Morris, M., Davis, G., Davis, F.: User Acceptance of Information Technology: Toward a Unified View. MIS Quarterly 27(3), 425-478 (2003)

29. UN.: World public sector report: On E-government survey, From E-government to Connected Governance, New York (2008) 